\title{
$\beta$-Carotene Production from Dunaliella salina Cultivated with Bicarbonate as Carbon Source
}

\author{
Yimei $\mathrm{Xi}^{\dagger}$, Jinghan $\mathrm{Wang}^{\dagger}$, Song Xue, and Zhanyou Chi* \\ School of Bioengineering, Dalian University of Technology, Dalian 116024, P.R. China
}

\begin{abstract}
Bicarbonate has been considered as a better approach for supplying $\mathrm{CO}_{2}$ to microalgae cells microenvironments than gas bubbling owing to cost-effectiveness and easy operation. However, the $\beta$-carotene production was too low in Dunaliella salina cultivated with bicarbonate in previous studies. Also, the difference in photosynthetic efficiency between these two carbon sources (bicarbonate and $\mathrm{CO}_{2}$ ) has seldom been discussed. In this study, the culture conditions, including $\mathrm{NaHCO}_{3}, \mathrm{Ca}^{2+}, \mathrm{Mg}^{2+}$ and microelement concentrations, were optimized when bicarbonate was used as carbon source. Under optimized condition, a maximum biomass concentration of $0.71 \mathrm{~g} / \mathrm{l}$ and corresponding $\beta$-carotene content of $4.76 \%$ were obtained, with $\beta$-carotene yield of $32.0 \mathrm{mg} / \mathrm{l}$, much higher than previous studies with $\mathrm{NaHCO}_{3}$. Finally, these optimized conditions with bicarbonate were compared with $\mathrm{CO}_{2}$ bubbling by online monitoring. There was a notable difference in $F_{v} / F_{m}$ value between cultivations with bicarbonate and $\mathrm{CO}_{2}$, but there was no difference in the $F_{v} / F_{m}$ periodic changing patterns. This indicates that the high concentration of $\mathrm{NaHCO}_{3}$ used in this study served as a stress factor for $\beta$-carotene accumulation, although high productivity of biomass was still obtained.
\end{abstract}

Keywords: Dunaliella salina, $\beta$-carotene, bicarbonate, microelement, carbon source

Received: October 16, 2019 Accepted: March 10, 2020

First published online: March 13, 2020

*Corresponding autho Phone: +86-132-3405-3986 E-mail: chizhy@dlut.edu.cn

${ }^{\dagger}$ These authors contributed equally to this work

Supplementary data for this paper are available on-line only at http://jmb.or.kr.

pISSN 1017-7825 elSSN 1738-8872

Copyright(C) 2020 by The Korean Society for Microbiology and Biotechnology

\section{Introduction}

Dunaliella salina is a halo-tolerant microalgae species that accumulates high levels of $\beta$-carotene [1,2]. Although it has been used in commercial production of carotene for several decades, its production cost is still very high, limiting its application to only high-value nutraceuticals [3]. For products of lower value but much larger market size, such as animal and aquaculture feed additives, the current production cost of Dunaliella is much too high to be economically feasible, and needs to be significantly reduced.

Carbon accounts for about $50 \%$ of microalgae's dry weight, and its supply is very important in the development of cost-effective microalgae cultivation processes. In conventional cultivation systems, inorganic carbon is usually supplied as gaseous $\mathrm{CO}_{2}$, which has caused serious technological difficulties in photobioreactor (PBR) design and operation $[4,5,6]$, ultimately resulting in high production cost. Recently, bicarbonate has been suggested as a better approach to supplying carbon, with the advantages of easy transportation, handling, and storage. In such conditions, an aeration-free PBR can be used as a low-cost cultivation system [7-10].

There have been some reports on employing sodium bicarbonate to stimulate $\beta$-carotene accumulation in D. salina $[8,9,11,12]$. However, $\beta$-carotene production reached in these studies was much lower than the conventional cultivation with $\mathrm{CO}_{2}$, amounting to only $8.25 \pm 0.01 \mathrm{mg} / \mathrm{l}$ [12], $7.10 \pm 0.08 \mathrm{mg} / \mathrm{l}$ [9], and 20.43 \pm $2.84 \mathrm{mg} / \mathrm{l}[8]$, respectively. These levels are too low to be used as routine practice in large-scale production. As a matter of fact, when bicarbonate is used as carbon source, the optimal culture condition for $\beta$-carotene accumulation may be different from that with $\mathrm{CO}_{2}$. In this situation, it is necessary to disclose the effects of different factors on cell growth and $\beta$-carotene accumulation with bicarbonate as carbon source.

Also, when bicarbonate is used in the culture, $\mathrm{pH}$ drift is inevitable, and $\mathrm{HCO}_{3}{ }^{-}$converts to $\mathrm{CO}_{3}{ }^{2-}$ at high $\mathrm{pH}$. Seawater is usually used as culture medium for Dunaliella sp., and the high concentration of $\mathrm{Ca}^{2+}$ and $\mathrm{Mg}^{2+}$ in it may precipitate with $\mathrm{CO}_{3}{ }^{2-}$, since $\mathrm{CaCO}_{3}$ precipitation usually occurs when $\mathrm{pH}$ exceeds 8.5, and $\mathrm{Mg}(\mathrm{OH})_{2}$ precipitation forms when $\mathrm{pH}$ exceeds 10 . Although $\mathrm{pH}$ adjustment with acid can avoid this precipitation, it is not practical for outdoor large-scale cultivation since additional chemicals and sophisticated equipment are required. An alternative method to avoid this precipitation is reducing the concentrations of $\mathrm{Ca}^{2+}$ and $\mathrm{Mg}^{2+}$, but this

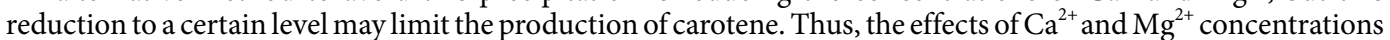
need to be carefully investigated.

$\beta$-carotene accumulation is usually triggered by environmental stress such as light, temperature, salinity, or nitrogen depletion $[13,14] . F_{v} / F_{m}$ is the photosystem II (PS II) maximum photochemical quantum yield. It is 
sensitive to stress conditions for microalgae, and has been established as a quantitative indicator that shows certain stress levels. For example, the value of $F_{v} / F_{m}$ can reflect fatty acid accumulation in response to nitrogen depletion [15]. $F_{v} / F_{m}$ was also used as an indicator in Dunaliella sp. in previous study to disclose the mechanism of $\beta$ carotene accumulation in response to different stresses [12]. Thus, the $F_{v} / F_{m}$ was monitored in this study, to compare the stress the cells experienced in cultivation with either bicarbonate or $\mathrm{CO}_{2}$, which finally affects the $\beta$ carotene accumulation.

The present study, therefore, investigated the effects of various factors on $D$. salina growth and $\beta$-carotene production when sodium bicarbonate is used as carbon source. Different concentrations of sodium bicarbonate, as well as $\mathrm{Ca}^{2+}$ and $\mathrm{Mg}^{2+}$ were investigated for $D$. salina growth and $\beta$-carotene accumulation. Central composite design experiments were carried out for studying the effect of microelements on biomass and $\beta$-carotene content of $D$. salina. Finally, maximal PS II quantum yield and $\beta$-carotene content were analyzed and compared between bicarbonate and $\mathrm{CO}_{2}$-based cultivation.

\section{Materials and Methods \\ Strain and Medium}

The microalgae D. salina CCAP 19/18 was purchased from Culture Collection of Algae and Protozoa agencies (UK), and it was maintained in Artificial Sea Water (ASW). The nutrient medium was $1.5 \mathrm{M} \mathrm{NaCl}, 5 \mathrm{mM} \mathrm{KNO}_{3}$, $4.5 \mathrm{mM} \mathrm{MgCl} 2 \cdot 6 \mathrm{H}_{2} \mathrm{O}, 0.5 \mathrm{mM} \mathrm{MgSO}_{4} \cdot 7 \mathrm{H}_{2} \mathrm{O}, 3 \mathrm{mM} \mathrm{CaCl} \cdot 2 \mathrm{H}_{2} \mathrm{O}, 0.13 \mathrm{mM} \mathrm{K}_{2} \mathrm{HPO}_{4}, 0.02 \mathrm{mM} \mathrm{FeCl}_{3}, 0.02 \mathrm{mM}$ EDTA, $25 \mathrm{mM} \mathrm{NaHCO}_{3}, 1 \mathrm{ml}$ of trace elements stock with $50 \mathrm{mM} \mathrm{H}_{3} \mathrm{BO}_{3}, 10 \mathrm{mM} \mathrm{MnCl} \mathrm{m}_{2} \cdot 4 \mathrm{H}_{2} \mathrm{O}, 0.8 \mathrm{mM}$ $\mathrm{ZnSO}_{4} \cdot 7 \mathrm{H}_{2} \mathrm{O}, 1.0 \mathrm{mMCuSO}_{4} \cdot 5 \mathrm{H}_{2} \mathrm{O}, 2 \mathrm{mMNaMoO}_{4} \cdot 2 \mathrm{H}_{2} \mathrm{O}, 1.5 \mathrm{mM} \mathrm{NaVO}_{3}, 0.8 \mathrm{mMCoCl}_{2} \cdot 6 \mathrm{H}_{2} \mathrm{O}$, and the pH was adjusted to 7.5 by addition $40 \mathrm{mM}$ of Tris-buffer [16]. Before inoculation, microalgae were cultivated in batch mode to promote fast growth in $500 \mathrm{~mL}$ conical flasks with light intensity of $40 \mu \mathrm{mol} / \mathrm{m}^{-2} / \mathrm{s}^{-1}$ and alternating $12 \mathrm{~h} /$ $12 \mathrm{~h} \mathrm{light/dark}$ cycles. After inoculation, the initial cell concentration in each horizontal photobioreactor (PBR) was about $0.2 \times 10^{6}$ cells $/ \mathrm{ml}^{-1}$. The horizontal PBRs were polystyrene boxes of $12 \mathrm{~cm} \times 12 \mathrm{~cm}$, with a working volume of $250 \mathrm{ml}$ and a light path of $20 \mathrm{~mm}$. Light was provided by white LEDs, with intensity on the top surface of the PBR controlled at $200 \mu \mathrm{mol} / \mathrm{m}^{-2} / \mathrm{s}^{-1}$ and under $12 \mathrm{~h} / 12 \mathrm{~h}$ light/dark cycles. Cultivation temperature was controlled at $25 \pm 0.5^{\circ} \mathrm{C}$ in the illumination incubator. Each experiment below was carried out in triplicate.

\section{Growth Analysis}

Cell numbers were counted daily using a hematocyto-meter. Dry weight (DW, g/l) was measured by using preweighed Whatman GF/C filters $[17,18]$. Ten milliliter cultures were filtered and washed three times with $2 \mathrm{ml}$ $0.5 \mathrm{M}$ ammonium bicarbonate and then were dried below $60^{\circ} \mathrm{C}$ for over $16 \mathrm{~h}$ until the weight was constant. The DW of the microalgae cells was calculated according to the final weight and volume of the filtered sample.

Analysis of microalgal $\beta$-carotene was based on methods described in Mojaat [19]. For $\beta$-carotene content measurement, $10 \mathrm{mg}$ of dried biomass was extracted with $1 \mathrm{ml}$ acetone and vortexed for $20 \mathrm{~s}$. Then, it was centrifuged at $10,000 \times g$ for $10 \mathrm{~min}$. This extraction was repeated twice. The extracts were filtered by $0.45-\mu \mathrm{m}$ pore size (PTFE) membrane syringe filters $\left(1.7 \mathrm{~cm}^{2}\right)$. All extracts were treated using amber glass vials with screw caps to protect carotenoids from degradation under light. The $\beta$-carotene analysis was carried out by High-Performance Liquid Chromatography (HPLC, Agilent Technologies 1100, USA). The mobile phase was 10\% acetonitrile and $90 \%$ methanol. The flow rate was $1 \mathrm{ml} / \mathrm{min}^{-1}$, and the detection wavelength was $452 \mathrm{~nm}$. The standard sample of $\beta$ carotene was purchased from Sigma (Sigma-Aldrich, USA).

\section{Experimental Design and Data Analysis}

Influence of sodium bicarbonate concentrations on $\boldsymbol{D}$. salina growth. To test the effect of $\mathrm{NaHCO}_{3}$ concentrations on D. salina CCAP 19/18, six concentration gradients were selected, i.e., 25, 50, 100, 200, 300, and $500 \mathrm{mM}$. The concentrations of $\mathrm{NaCl}, \mathrm{Ca}^{2+}$, and $\mathrm{Mg}^{2+}$ in the culture medium were $1.5 \mathrm{M}, 3.0 \mathrm{mM}$, and $5.0 \mathrm{mM}$, respectively.

Influence of $\mathrm{Ca}^{2+}$ and $\mathrm{Mg}^{2+}$ concentrations on D. salina growth. When optimizing the concentrations of $\mathrm{Ca}^{2+}$ and $\mathrm{Mg}^{2+}$ for $D$. salina growth, gradients of $\mathrm{Ca}^{2+}$ and $\mathrm{Mg}^{2+}$ concentrations were from 0.3 to $3.0 \mathrm{mM}$, and from 0.5 to $5.0 \mathrm{mM}$, respectively, as listed in Table 1 . Optimized $\mathrm{NaHCO}_{3}$ concentration $(200 \mathrm{mM})$ was adopted for all cultures with various $\mathrm{Ca}^{2+}$ and $\mathrm{Mg}^{2+}$ concentrations.

\section{Central Composite Design}

With a Plackett-Burman (PB) design, three significant microelements listed in Table 2 were screened from $\mathrm{FeCl}_{3} \cdot 6 \mathrm{H}_{2} \mathrm{O}, \mathrm{H}_{3} \mathrm{BO}_{3}, \mathrm{ZnSO}_{4} \cdot 7 \mathrm{H}_{2} \mathrm{O}, \mathrm{CoCl}_{2} \cdot 6 \mathrm{H}_{2} \mathrm{O}, \mathrm{CuSO}_{4} \cdot 5 \mathrm{H}_{2} \mathrm{O}, \mathrm{MnCl}_{2} \cdot 4 \mathrm{H}_{2} \mathrm{O}, \mathrm{NaMoO}_{4} \cdot 2 \mathrm{H}_{2} \mathrm{O}$, and $\mathrm{NaVO}_{3}$, as

Table 1. Different concentrations of $\mathrm{Ca}^{2+}, \mathrm{Mg}^{2+}$ investigated in this study.

\begin{tabular}{ccc}
\hline No. & $\mathrm{Ca}^{2+}(\mathrm{mM})$ & $\mathrm{Mg}^{2+}(\mathrm{mM})$ \\
\hline A & 0.3 & 0.5 \\
B & 0.6 & 1.0 \\
C & 1.2 & 2.0 \\
D & 1.8 & 3.0 \\
E & 2.4 & 4.0 \\
F & 3.0 & 5.0 \\
\hline
\end{tabular}


Table 2. The coded and real values of the independent variables in the central composite design.

\begin{tabular}{lcccccc}
\hline Variables & Unit & -2 & -1 & 0 & 1 & 2 \\
\hline $\mathrm{FeCl}_{3} \cdot 6 \mathrm{H}_{2} \mathrm{O}$ & $\mu \mathrm{M}$ & 1.85 & 5.92 & 9.99 & 14.1 & 18.1 \\
$\mathrm{CoCl}_{2} \cdot 6 \mathrm{H}_{2} \mathrm{O}$ & $\mu \mathrm{M}$ & 0.34 & 0.97 & 1.60 & 2.23 & 2.86 \\
$\mathrm{NaVO}_{3}$ & $\mu \mathrm{M}$ & 0.33 & 0.9 & 1.48 & 2.05 & 2.62 \\
\hline
\end{tabular}

displayed in Table S1. A central composite design was used to investigate their effects on dry cell weight and $D$. salina $\beta$-carotene yield. The design matrix was a $2^{4}$ full factor design combined with five central points, and eight axial points where one variable was set at an extreme level while other variables were set at their central point levels. The coded and real values of each parameter are shown in Table 2. Based on Table 3, the responses (cell dry weight and $\beta$-carotene yield) were correlated as a function of variables by a second-order polynomial equation, i.e.,

$$
\mathrm{Y}=\beta_{0}+\sum \beta_{\mathrm{i}} \mathrm{X}_{\mathrm{i}}+\sum \beta_{\mathrm{i}} \mathrm{X}_{\mathrm{i}}^{2}+\sum \beta_{\mathrm{ij}} \mathrm{X}_{\mathrm{i}} \mathrm{X}_{\mathrm{j}}
$$

where $Y$ is the predicted response, $\beta$ is the coefficient of the equation, and $x_{i}$ and $x_{j}$ are the coded levels of variables $i$ and $j$, respectively. The software Design-Expert (Stat-Ease Inc., USA) was adopted for this correlation through non-linear regression. An F-test was used to evaluate the significance of the models.

\section{$\mathrm{NaHCO}_{3}$ vs. $\mathrm{CO}_{2}$ Cultivation with Online Monitoring}

To confirm the experimental results obtained from the $\mathrm{NaHCO}_{3}$, D. salina was cultivated with a multi-deviceequipped flat-plate photobioreactor (PBR)-Algal station [15] in both $\mathrm{NaHCO}_{3}$-based (optimal $\mathrm{NaHCO}_{3}$ concentration) and $\mathrm{CO}_{2}$-based (2\%) cultivations. Light was provided by white LEDs, with intensity on the top surface of the PBR controlled at $200 \mu \mathrm{mol} / \mathrm{m}^{-2} / \mathrm{s}^{-1}$ and under $12 \mathrm{~h} / 12 \mathrm{~h}$ light/dark cycles. Light path of the PBR was $20 \mathrm{~mm}$ and total cultivation volume was $1 \mathrm{~L}$. The cultivation temperature was automatically controlled at $25 \pm 0.5^{\circ} \mathrm{C}$. Cultures in the PBR were agitated with $0.2-\mu \mathrm{m}$ membrane-filtered air at $200 \mathrm{ml} / \mathrm{min}\left(\mathrm{NaHCO}_{3}\right.$-based culture) or with $2 \% \mathrm{CO}_{2}\left(\mathrm{CO}_{2}\right.$-based culture). Maximal PS II quantum yield $\left(F_{v} / F_{m}\right), \mathrm{OD}$, and $\mathrm{pH}$ value were recorded online.

\section{Results}

Effect of $\mathrm{NaHCO}_{3}$ Concentration on Cell Growth and $\beta$-Carotene Accumulation

Growth curves for $D$. salina cultivated under a series of $\mathrm{NaHCO}_{3}$ concentrations are shown in Fig.1A, indicating D. salina could grow well in medium with $\mathrm{NaHCO}_{3}$ as carbon source. Cell densities of 25, 50, and $100 \mathrm{mM}$ $\mathrm{NaHCO}_{3}$ cultures increased rapidly during the first 3 days of cultivation, and were higher than those of 200, 300, and $500 \mathrm{mM}$ cultures. After that, cell density decreased in cultures with $\mathrm{NaHCO}_{3}$ concentrations lower than $100 \mathrm{mM}$. The lowest cell density was observed in $25 \mathrm{mM} \mathrm{NaHCO}_{3}$ and the highest cell density was recorded in 200 $\mathrm{mMNaHCO}_{3}$ culture, which was $1.65 \times 10^{6}$ cells $/ \mathrm{ml}^{-1}$ on Day 7. As far as the DW is concerned, the highest DW was obtained on Day 7 with $200 \mathrm{mM} \mathrm{NaHCO}$ concentration $(0.66 \pm 0.02 \mathrm{~g} / \mathrm{l})$, whereas the lowest DW of $0.35 \pm 0.01 \mathrm{~g} / \mathrm{l}$ was obtained in culture with $50 \mathrm{mM} \mathrm{NaHCO}_{3}$ (Fig. 2). It was interesting that $D$. salina was able to grow in culture with $500 \mathrm{mM} \mathrm{NaHCO}_{3}$, although $200 \mathrm{mM} \mathrm{NaHCO}_{3}$ enabled the fastest growth.

Correspondingly, $\mathrm{pH}$ variations of these cultures were displayed in Fig. 1B. The $\mathrm{pH}$ values of the six cultures spiked on Day 1 then increased slowly afterwards. At Day 7, the highest and lowest $\mathrm{pH}$ values were obtained in $25 \mathrm{mM}$ culture $(\mathrm{pH}=10.3)$ and $500 \mathrm{mM}$ culture $(\mathrm{pH}=9.8)$, respectively. For cultures with $\geq 100 \mathrm{mM} \mathrm{NaHCO}_{3}$,

Table 3. The central composite design of the significant (in coded level) with DW and $\beta$-carotene yield as responses.

\begin{tabular}{cccccc}
\hline Run & $\mathrm{FeCl}_{3} \cdot 6 \mathrm{H}_{2} \mathrm{O}$ & $\mathrm{CoCl}_{2} \cdot 6 \mathrm{H}_{2} \mathrm{O}$ & $\mathrm{NaVO}_{3}$ & $\mathrm{DW}(\mathrm{g} / \mathrm{l})$ & $\beta$-carotene $(\%)$ \\
\hline 1 & 1 & 1 & -1 & 0.645 & 4.35 \\
2 & 1 & -1 & 1 & 0.637 & 4.27 \\
3 & -1 & 1 & 1 & 0.685 & 4.76 \\
4 & -1 & -1 & -1 & 0.664 & 4.27 \\
5 & -2 & 0 & 0 & 0.71 & 4.28 \\
6 & 2 & 0 & 0 & 0.629 & 4.59 \\
7 & 0 & -2 & 0 & 0.691 & 4.16 \\
8 & 0 & 2 & 0 & 0.665 & 4.55 \\
9 & 0 & 0 & -2 & 0.671 & 4.21 \\
10 & 0 & 0 & 2 & 0.708 & 3.85 \\
12 & 0 & 0 & 0 & 0.695 & 3.97 \\
13 & 0 & 0 & 0 & 0.696 & 3.94 \\
15 & 0 & 0 & 0 & 0.707 & 3.86 \\
\end{tabular}



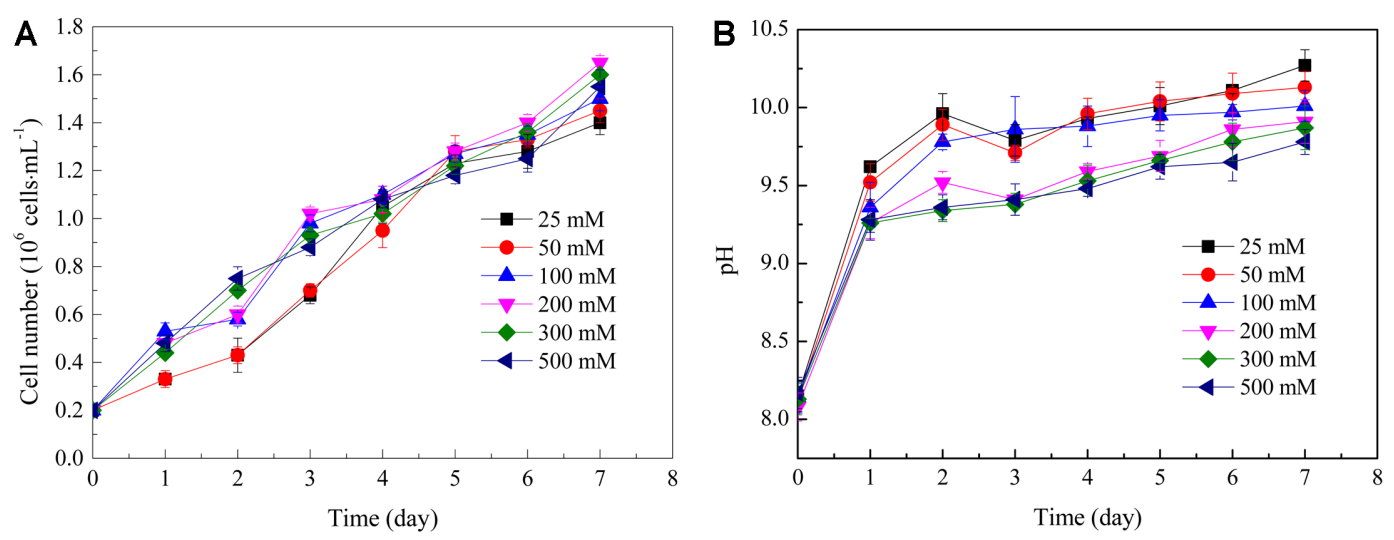

Fig. 1. Effect of different concentrations of $\mathrm{NaHCO}_{3}$ on (A) D. salina cell density; (B) $\mathrm{pH}$ of the culturing broth. Values represented as mean $\pm \operatorname{SD}(n=3)$.

$\mathrm{pHs}$ in these cultures were below 10.0 during the whole cultivation time. When correlating $\mathrm{pH}$ with microalgal growth, cultures with higher $\mathrm{pH}$ resulted in lower growth rates, indicating that elevated $\mathrm{pH}$ inhibited growth of $D$. salina, although it was able to grow at $\mathrm{pH}$ value higher than 10.0. Moreover, these results indicated that $\mathrm{NaHCO}_{3}$ had a strong buffering effect on $\mathrm{pH}$.

When correlating $\mathrm{NaHCO}_{3}$ concentration with DW, the cellular $\beta$-carotene content levels of $D$. salina grown under different $\mathrm{NaHCO}_{3}$ concentrations were displayed in Fig. 2. The highest $\beta$-carotene content of $4.20 \pm 0.12 \% \mathrm{DW}$ was obtained in culture with $200 \mathrm{mM} \mathrm{NaHCO}_{3}$, and the corresponding $\beta$-carotene yield was $27.72 \pm 1.65 \mathrm{mg} / \mathrm{l}$. In contrast, the lowest $\beta$-carotene content of $2.1 \pm 0.11 \%$ was obtained in $25 \mathrm{mM}$ culture, reaching $\beta$-carotene yield of $9.77 \pm 0.45 \mathrm{mg} / \mathrm{l}$. In culture with $500 \mathrm{mM} \mathrm{NaHCO}{ }_{3}$ concentration, although high $\beta$-carotene content of $3.7 \pm$ $0.11 \%$ was obtained, the overall available $\beta$-carotene yield was only $12.95 \pm 0.46 \mathrm{mg} / \mathrm{l}$ owing to limited microalgal growth. From these results, it was implied that $\mathrm{NaHCO}_{3}$ concentration could greatly influence cell growth and $\beta$ carotene accumulation of $D$. salina, and $200 \mathrm{mM}$ was optimal for both biomass and $\beta$-carotene production in this study.

\section{Effect of $\mathrm{Ca}^{2+}$ and $\mathrm{Mg}^{2+}$ Concentrations on Cell Growth and $\beta$-Carotene Accumulation}

The correlation between $\mathrm{Ca}^{2+}, \mathrm{Mg}^{2+}$ and growth of $D$. salina was shown in Fig. 3A. Cell numbers ranged from 1.40 to $1.65 \times 10^{6} \mathrm{cells} / \mathrm{ml}$ under different $\mathrm{Ca}^{2+}$ and $\mathrm{Mg}^{2+}$ concentrations, and significant differences were observed among all cultures on Day $7(p=0.03<0.1)$. The highest cell number was obtained in culture with $3.0 \mathrm{mM} \mathrm{Ca}^{2+}$ and $5.0 \mathrm{mM} \mathrm{Mg}^{2+}$, while the lowest cell number was obtained in culture with $0.3 \mathrm{mM} \mathrm{Ca}^{2+}$ and $0.5 \mathrm{mM} \mathrm{Mg}^{2+} \cdot \mathrm{pH}$ values of all cultures on Day 7 displayed insignificant differences $(p=0.12>0.1)$, with values around 9.8 (Fig. 3B).

As shown in Fig. 4, DW was positively correlated with $\mathrm{Ca}^{2+}$ and $\mathrm{Mg}^{2+}$ concentrations, with the highest and lowest DW $(0.69 \mathrm{~g} / \mathrm{l}$ and $0.61 \mathrm{~g} / \mathrm{l})$ respectively at the same culturing conditions regarding cell numbers (Fig. 3A). In contrast, $\beta$-carotene content was negatively correlated with $\mathrm{Ca}^{2+}$ and $\mathrm{Mg}^{2+}$ concentrations, with the highest and lowest $\beta$-carotene content (respectively $4.5 \%$ and $4.1 \%$ ) obtained at culturing conditions opposite to those of cell density and DW. It was noteworthy that $\beta$-carotene yield obtained in cultures with different $\mathrm{Ca}^{2+}$ and $\mathrm{Mg}^{2+}$ were around the same levels $(26.2$ to $27.5 \mathrm{mg} / \mathrm{l})$, displaying no significant differences $(p=0.87>0.10)$. Thus, low concentration $\mathrm{Ca}^{2+}$ and $\mathrm{Mg}^{2+}$ of $0.3 \mathrm{mM}$ and $0.5 \mathrm{mM}$ respectively, are adequate for $\beta$-carotene accumulation.

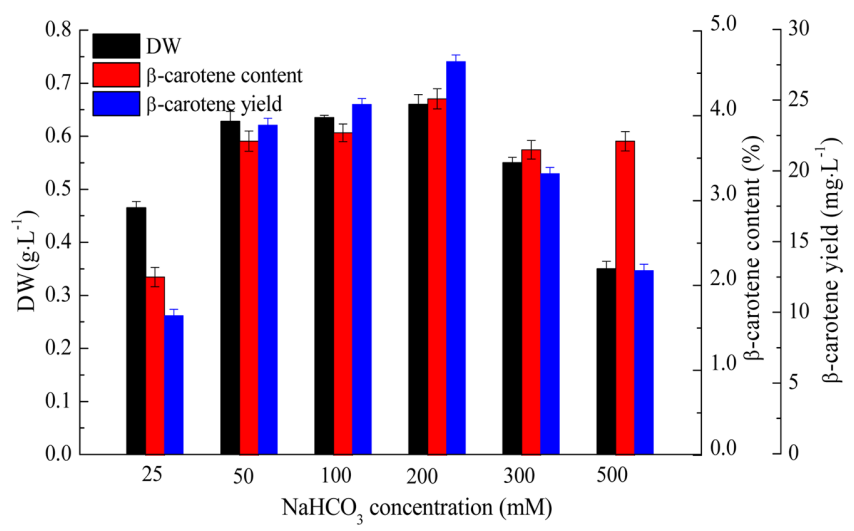

Fig. 2. Effect of $\mathrm{NaHCO}_{3}$ concentrations on DW, $\beta$-carotene content, and $\beta$-carotene yield of $D$. salina. Values represented as mean $\pm \operatorname{SD}(n=3)$. 

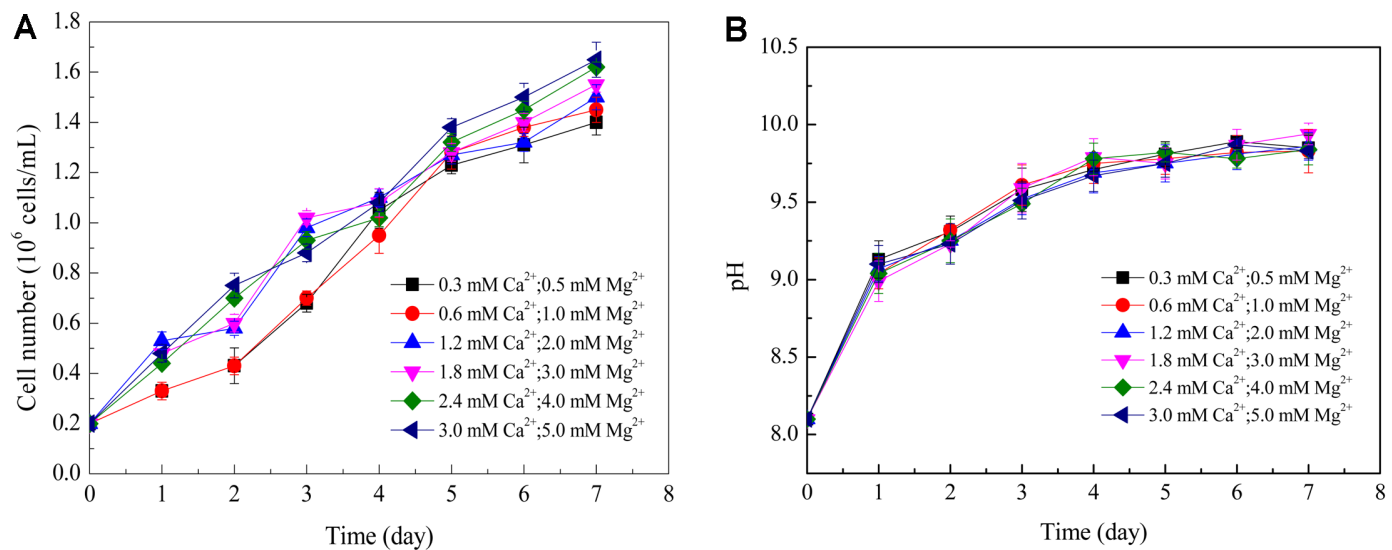

Fig. 3. Effect of $\mathrm{Ca}^{2+}$ and $\mathrm{Mg}^{2+}$ concentrations on (A) cell number of D. salina; (B) $\mathrm{pH}$ of the culturing broth. Values represented as mean $\pm S D(n=3)$.

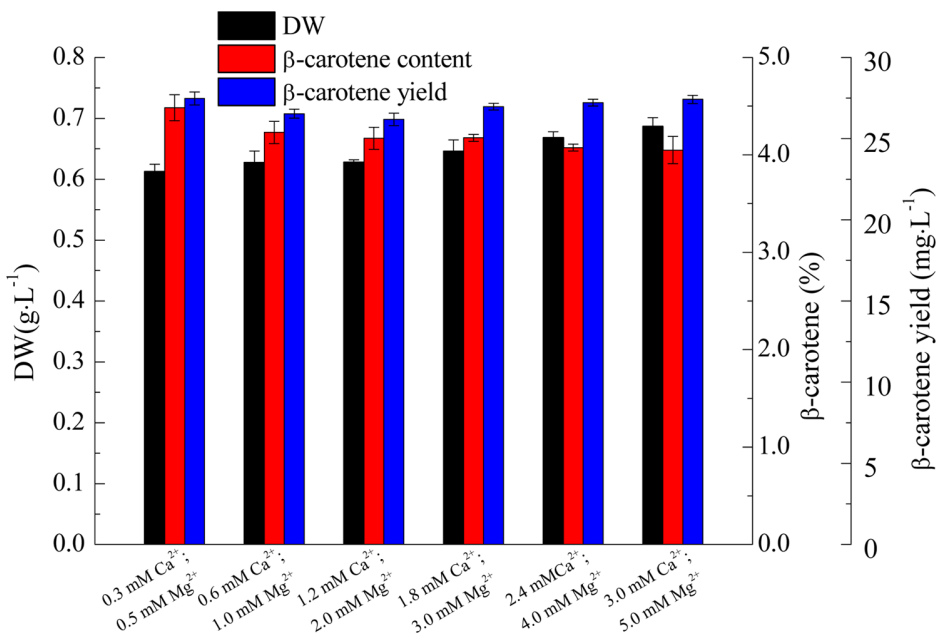

Fig. 4. Effect of $\mathrm{Ca}^{2+}, \mathrm{Mg}^{2+}$ concentrations on DW and $\beta$-carotene accumulation of $D$. salina. Values represent as mean $\pm \operatorname{SD}(n=3)$.

Effect of Micronutrients on Cell Growth and $\beta$-Carotene Accumulation

Optimization of significant factors. For central composite design, the central point values and level ranges of three significant factors were selected according to the PB design results (Table S1). As shown in Table 3, the central point in the central composite design was repeated five times, and standard deviation of these five replicates used to determine the experimental errors were $0.008 \mathrm{~g} / \mathrm{l}$ for DW, and $0.07 \%$ for $\beta$-carotene content. The experimental data of DW and $\beta$-carotene content in Table 3 were correlated as functions of the three variables by a second-order polynomial equation using the Design-Expert software. The coefficient values in Eq. (1) and their $p$ -

Table 4. The values of coefficients in the second-order polynomial and the associated statistical test for DW and $\beta$-carotene.

\begin{tabular}{lcccccc}
\hline \multirow{2}{*}{ Variable } & \multicolumn{3}{c}{ DW } & \multicolumn{3}{c}{$\beta$-carotene } \\
\cline { 2 - 7 } & F-value & $p$-value & Estimate & F-value & $p$-value & Estimate \\
\hline Model & 12.06 & 0.0068 & 0.7 & 12.11 & 0.0067 & 3.96 \\
$\mathrm{~A}-\mathrm{FeCl}_{3} \cdot 6 \mathrm{H}_{2} \mathrm{O}$ & 36.44 & 0.0018 & -0.029 & 3.05 & 0.0412 & 0.1 \\
$\mathrm{~B}-\mathrm{CoCl}_{2} \cdot 6 \mathrm{H}_{2} \mathrm{O}$ & 3.75 & 0.1104 & $-9.19 \mathrm{E}-03$ & 5.52 & 0.0657 & 0.14 \\
$\mathrm{C}-\mathrm{NaVO}_{3}$ & 7.6 & 0.04 & 0.013 & 4.7 & 0.0824 & -0.13 \\
$\mathrm{AB}$ & 2.15 & 0.2027 & $9.83 \mathrm{E}-03$ & 7.66 & 0.0395 & -0.23 \\
$\mathrm{AC}$ & 6.01 & 0.0579 & -0.016 & $3.09 \mathrm{E}-03$ & 0.9578 & $-4.61 \mathrm{E}-03$ \\
$\mathrm{BC}$ & 3.14 & 0.1366 & -0.012 & $1.348 \mathrm{E}-07$ & 0.9997 & -0.00003048 \\
$\mathrm{~A} \wedge 2$ & 27.2 & 0.0034 & -0.018 & 70.58 & 0.0004 & 0.36 \\
$\mathrm{~B} \wedge 2$ & 15.77 & 0.0106 & -0.014 & 15.27 & 0.0113 & 0.17 \\
$\mathrm{C} \wedge 2$ & 5.23 & 0.0709 & $-7.82 \mathrm{E}-03$ & 0.004034 & 0.9518 & 0.002685
\end{tabular}




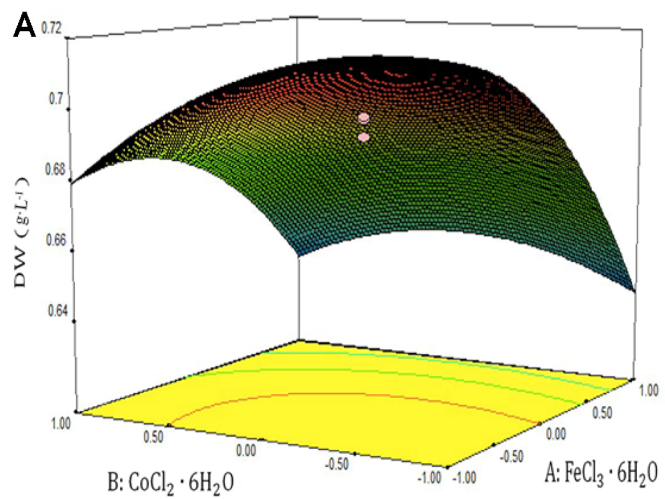

B

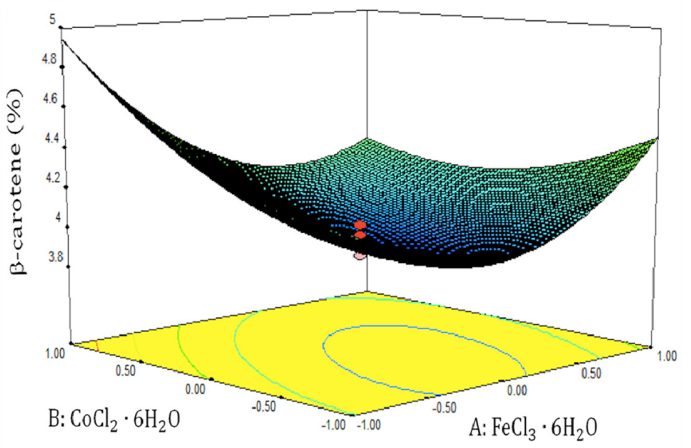

Fig. 5. Three-dimensional response surface plot of (A) DW and (B) $\beta$-carotene content as a function of $\mathrm{FeCl}_{3} \cdot 6 \mathrm{H}_{2} \mathrm{O}$ and $\mathrm{CoCl}_{2} \cdot 6 \mathrm{H}_{2} \mathrm{O}$.

values and $F$-values were listed in Table 4 . The optimal value of the three variables were derived by Design-Expert software, and the maximum dry cell weight of $0.71 \mathrm{~g} / \mathrm{l}$ was obtained in culture with $1.85 \mu \mathrm{M} \mathrm{FeCl}_{3} \cdot 6 \mathrm{H}_{2} \mathrm{O}, 1.6 \mu \mathrm{M}$ $\mathrm{CoCl}_{2} \cdot 6 \mathrm{H}_{2} \mathrm{O}$, and $1.48 \mu \mathrm{M} \mathrm{NaVO}_{3}$ concentrations. The maximum $\beta$-carotene content of $4.76 \%$ was obtained in culture with $5.92 \mu \mathrm{M} \mathrm{FeCl}_{3} \cdot 6 \mathrm{H}_{2} \mathrm{O}, 2.23 \mu \mathrm{M} \mathrm{CoCl}_{2} \cdot 6 \mathrm{H}_{2} \mathrm{O}$, and $2.05 \mu \mathrm{M} \mathrm{NaVO}$. From $p$-levels in Table 4 and the response surfaces in Fig. 5, it is evident that microelements, especially $\mathrm{Fe}^{3+}$ and $\mathrm{Co}^{2+}$ and their concentrations, can have significant influences on $D$. salina growth and $\beta$-carotene accumulation.

Three-dimension surface responses were plotted to illustrate the relationship between the variables and their responses. Because the statistical analysis indicated that $\mathrm{FeCl}_{3} \cdot 6 \mathrm{H}_{2} \mathrm{O}$ and $\mathrm{CoCl}_{2} \cdot 6 \mathrm{H}_{2} \mathrm{O}$ concentration had more significant effects on the responses than $\mathrm{NaVO}_{3}$ concentration ( $p$-level, Table 4), the responses (DW and $\beta$ carotene content) were plotted as the functions of $\mathrm{FeCl}_{3} \cdot 6 \mathrm{H}_{2} \mathrm{O}$ and $\mathrm{CoCl}_{2} \cdot 6 \mathrm{H}_{2} \mathrm{O}$. As shown in Fig. 5A, low concentrations of $\mathrm{FeCl}_{3} \cdot 6 \mathrm{H}_{2} \mathrm{O}$ and $\mathrm{CoCl}_{2} \cdot 6 \mathrm{H}_{2} \mathrm{O}$ led to an increase in $\mathrm{DW}$, but $\beta$-carotene content increased with augmentation of $\mathrm{CoCl}_{2} \cdot 6 \mathrm{H}_{2} \mathrm{O}$ and $\mathrm{FeCl}_{3} \cdot 6 \mathrm{H}_{2} \mathrm{O}$ concentrations (Fig. $5 \mathrm{~B}$ ).

\section{Verification of Optimized Culture Conditions}

The optimal conditions determined from the central composite design were verified by comparing the experimental data obtained at these conditions with that predicted from central composite design (Eq. (1) and Table 4). Three verification experiments were conducted, which were respectively optimal for DW, $\beta$-carotene content, and both DW and $\beta$-carotene content (Table 5). For DW experiment under optimized condition, the experimental data was $0.77 \pm 0.01 \mathrm{~g} / \mathrm{l}$, while the predicted value was $0.86 \mathrm{~g} / \mathrm{l}$, indicating $9-10 \%$ deviation. As for the condition optimal for $\beta$-carotene content, experimental data was $4.78 \% \pm 0.04$, while the predicted value was $4.73 \%$, indicating a deviation of less than $5 \%$ (Table 5 ). With the second-order polynomial equation obtained in this study, the calculated DW (before optimizing the microelements) was $0.67 \mathrm{~g} / \mathrm{l}$, and the $\beta$-carotene content was $4.2 \%$. After the microelement optimization, DW was calculated as $0.78 \mathrm{~g} / \mathrm{l}$, and $\beta$-carotene content was $4.78 \%$ (Table 5). These experiments verified the effectiveness of the model developed in this study.

Comparisons between Cultivations with $\mathrm{NaHCO}_{3}$ and $\mathrm{CO}_{2}$

After 5 days of cultivation with supply of two different carbon sources, the growth showed significant differences in both $\mathrm{OD}_{680}(p<0.01)$ and DW $(p<0.01)$. The initial ODs were similar $\left(0.78\right.$ for $\mathrm{NaHCO}_{3}$-based and 0.79 for $\mathrm{CO}_{2}$-based) and then increased to $5.65 \pm 0.17$ and $6.58 \pm 0.23$, respectively (Table 6), and the corresponding final DWs were $0.89 \pm 0.10$ and $1.09 \pm 0.08 \mathrm{~g} / \mathrm{l}$, respectively (Table 6 ). The productivity in cultures

Table 5. Comparison of experimental and predicted DW and $\beta$-carotene content at optimal culture conditions.

\begin{tabular}{|c|c|c|c|}
\hline Culture conditions & & $\mathrm{DW}(\mathrm{g} / \mathrm{l})$ & $\beta$-carotene content (\%) \\
\hline \multirow{6}{*}{$\begin{array}{l}\text { Optimal for DW } \\
200 \mathrm{mM} \mathrm{NaHCO}_{3}, 0.45 \mathrm{mM} \mathrm{MgCl}_{2} \cdot 6 \mathrm{H}_{2} \mathrm{O}, 0.05 \mathrm{mM} \\
\mathrm{MgSO}_{4} \cdot 7 \mathrm{H}_{2} \mathrm{O}, 0.3 \mathrm{mM} \mathrm{CaCl} \cdot 2 \mathrm{H}_{2} \mathrm{O}, 1.85 \mu \mathrm{M} \mathrm{FeCl}_{3} \text {, } \\
1.5 \mu \mathrm{M} \mathrm{NaVO} \\
\text { All other conditions were as described in section } \\
\text { Materials and Methods }\end{array}$} & Predicted & 0.86 & $4.11 \%$ \\
\hline & Experimental data & $0.77 \pm 0.01$ & $4.23 \% \pm 0.01$ \\
\hline & Deviation (\%) & -10.00 & +2.90 \\
\hline & & & \\
\hline & & & \\
\hline & & & \\
\hline \multirow{3}{*}{$\begin{array}{l}\text { Optimal for } \beta \text {-carotene content } \\
5.92 \mu \mathrm{M} \mathrm{FeCl}_{3}, 2.0 \mu \mathrm{M} \mathrm{NaVO}_{3}, 2.2 \mu \mathrm{M} \mathrm{CoCl}_{2} \cdot 6 \mathrm{H}_{2} \mathrm{O} \text {, all } \\
\text { other conditions were as described for "optimal DW" }\end{array}$} & Predicted & 0.76 & $4.86 \%$ \\
\hline & Experimental data & $0.69 \pm 0.02$ & $4.78 \% \pm 0.04$ \\
\hline & Deviation (\%) & -9.20 & -1.60 \\
\hline \multirow{3}{*}{$\begin{array}{l}\text { Optimal for DW \& } \beta \text {-carotene } \\
5.92 \mu \mathrm{M} \mathrm{FeCl}_{3}, 2.0 \mu \mathrm{M} \mathrm{NaVO}_{3}, 2.2 \mu \mathrm{M} \mathrm{CoCl}_{2} \cdot 6 \mathrm{H}_{2} \mathrm{O} \text {, all } \\
\text { other conditions were as described for "optimal DW" }\end{array}$} & Predicted & 0.78 & $4.73 \%$ \\
\hline & Experimental data & $0.71 \pm 0.05$ & $4.52 \% \pm 0.04$ \\
\hline & Deviation (\%) & -9.00 & -4.60 \\
\hline
\end{tabular}


Table 6. Comparison of biomass, $\beta$-carotene yield, biomass productivities in cultivation with different carbon sources.

\begin{tabular}{lccccc}
\hline \multicolumn{1}{c}{ Treatment } & Day & OD680 & $\begin{array}{c}\text { Dry weight } \\
(\mathrm{g} / \mathrm{l})\end{array}$ & $\begin{array}{c}\beta \text {-carotene yield } \\
(\mathrm{mg} / \mathrm{l})\end{array}$ & $\begin{array}{c}\text { Biomass productivity } \\
\left(\mathrm{g} / \mathrm{l} / \mathrm{d}^{-1}\right)\end{array}$ \\
\hline $2 \%-\mathrm{CO}_{2}$ & 0 & $0.78(0.01)$ & $0.16(0.02)$ & $1.04(0.03)$ & \\
$2 \%-\mathrm{CO}_{2}$ & 5 & $5.65^{* *}(0.17)$ & $1.09^{*}(0.08)$ & $23.8^{* \star}(0.5)$ & 0.21 \\
$200 \mathrm{mM} \mathrm{NaHCO}_{3}$ & 0 & $0.79(0.02)$ & $0.16(0.02)$ & $1.04(0.03)$ & \\
$200 \mathrm{mM} \mathrm{NaHCO}_{3}$ & 5 & $6.58^{* *}(0.23)$ & $0.89^{\star}(0.10)$ & $41.5^{\star *}(0.2)$ & 0.18 \\
\hline
\end{tabular}

Values are mean $( \pm \mathrm{SD})$ of $n=3$ cultivations per treatment, ${ }^{*}$ represent the significant effect $(p<0.05)$ and ${ }^{* *}$ represent the very significant effect $(p<0.01)$

with $\mathrm{NaHCO}_{3}$ and $\mathrm{CO}_{2}$ were 0.18 and $0.21 \mathrm{~g} / \mathrm{l}^{-1} / \mathrm{d}^{-1}$, respectively. Clearly, the $\mathrm{CO}_{2}$-based mode provided a better growth environment for D. salina, resulting in a $14.2 \%$ and $22.4 \%$ higher OD and DW than the $\mathrm{NaHCO}_{3}$-based mode. The $\mathrm{pH}$ varied from $6.7 \pm 0.1$ to $8.3 \pm 0.1$ in the $\mathrm{CO}_{2}$-based mode, while the $\mathrm{pH}$ varied from $8.0 \pm 0.11$ to 9.5 \pm 0.1 in the $\mathrm{NaHCO}_{3}$-based mode (Fig. 6B).

Moreover, the $200 \mathrm{mM}$ bicarbonate had positive effects on the productivity of target value chemicals, $\beta$ carotene, showing the highest carotenoid concentration in the $\mathrm{NaHCO}_{3}$-based condition, $4.7 \%(41.5 \pm 0.2 \mathrm{mg} / \mathrm{l})$ (Fig. 6D, Table 6), this value was significantly higher than that with $\mathrm{CO}_{2}$-based condition, $2.2 \%(23.8 \pm 0.3 \mathrm{mg} / \mathrm{l})$. Also, the difference between the DW and $\beta$-carotene content in Figs. 6 and 2 should be due to microelement optimization, as evidenced in Fig. 5 and Table 4.

The changing patterns in $F_{v} / F_{m}$ are depicted in Fig. $6 \mathrm{C}$, and the $F_{v} / F_{m}$ of D. salina changed periodically following changes in light under two carbon supply conditions, but exhibited similar patterns. Notably, the $F_{v} / F_{m}$ followed 'sine' trends during the whole culture light/dark period. As for $2 \% \mathrm{CO}_{2}$-based condition, during the light period, the $F_{v} / F_{m}$ decreased quickly from 0.73 to the lowest value 0.68 within the first $3 \mathrm{~h}$ and then increased gradually to the highest value $(0.77)$ until the darkness period. During the $10 \mathrm{~h}$ darkness period, the $F_{v} / F_{m}$ decreased gradually but was significantly higher than that in the $14 \mathrm{~h}$ illumination period. For the $\mathrm{NaHCO}_{3}$-based culture condition, it was found that lowest $F_{v} / F_{m}$ values were significantly lower than $\mathrm{CO}_{2}$-based mode $(p=0.0003)$, and the lowest value of $F_{v} / F_{m}$ in the $\mathrm{CO}_{2}$-based mode was 0.05 higher than in the $\mathrm{NaHCO}_{3}$-based culture.
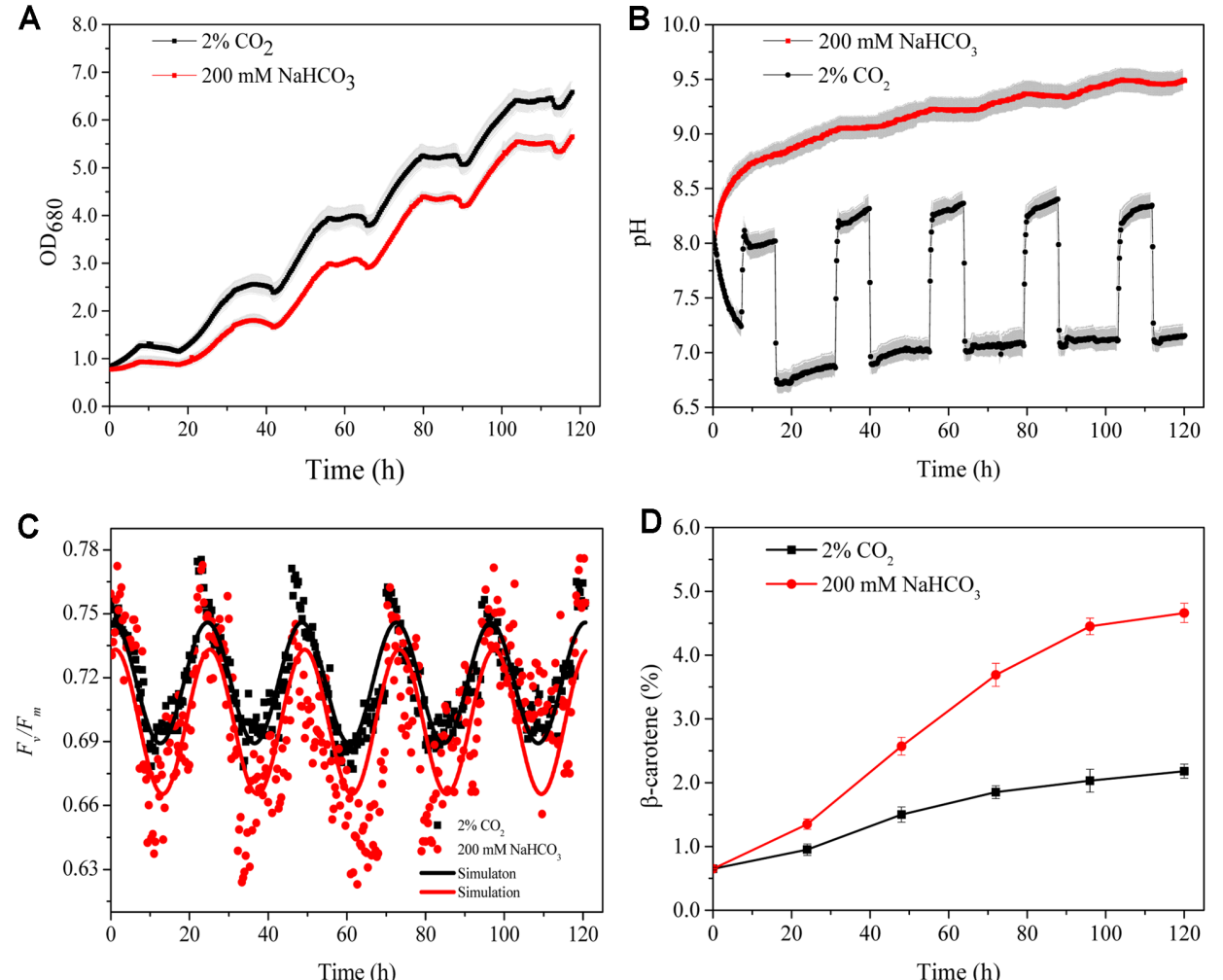

Fig. 6. $\mathrm{NaHCO}_{3}$-based cultivation vs. $\mathrm{CO}_{2}$-based cultivation by online monitoring (A) Growth curve of D. salina; (B) $\mathrm{pH}$ curve; (C) $F_{v} / F_{m}$ curve; (D) $\beta$-carotene content. The shaded areas indicate the standard error of the line values. 


\section{Discussion}

Although several studies have indicated that $D$. salina grew well in high concentration of bicarbonate, this study is the first one that reported $D$. salina can accumulate a good amount of $\beta$-carotene under such cultivation conditions. Table 7 compared the $\beta$-carotene content and $\beta$-carotene yield of Dunaliella strains in available literature. For $D$. salina CCAP 19/18, the strain used in this study, it accumulated only $2.26 \mathrm{mg} / \mathrm{l} \beta$-carotene when cultured with $20 \mathrm{mM} \mathrm{NaHCO}_{3}$ [20]. Also, the $\beta$-carotene yield obtained in this study is much higher than previous studies with other strains in Dunaliella. For example, it is about 4-fold of the yield of D. salina V-101 with $100 \mathrm{mM}$ $\mathrm{NaHCO}_{3}\left[12\right.$ ], and about 1.6-fold of Dunaliella sp. with $60 \mathrm{mM} \mathrm{NaHCO}_{3}$ [7]. Actually, $200 \mathrm{mM} \mathrm{NaHCO}_{3}$ supported better cell growth than other concentrations, but it is lower than that with $2 \% \mathrm{CO}_{2}$ (Table 6). Since $200 \mathrm{mM}$ bicarbonate resulted in a decreased value of $F_{v} / F_{m}$ (Fig. 6C), it is considered as a stress, but this is favorable for $\beta$ carotene production. However, the commonly observed stagnant growth under stress was not found in this study, since the obtained DW of $0.71 \pm 0.05 \mathrm{~g} / \mathrm{l}^{-1}$ is quite comparable with those observed without stress [15]. Thus, this study provided a feasible approach for $\beta$-carotene production from $D$. salina with bicarbonate as carbon source.

Precipitation appeared in culture with $200 \mathrm{mM} \mathrm{NaHCO}_{3}$ along with $3.0 \mathrm{mM} \mathrm{Ca}^{2+}$ and $5.0 \mathrm{mM} \mathrm{Mg}^{2+}$, since they react with excessive $\mathrm{CO}_{3}{ }^{2-}$ at high pH (equilibrium $\mathrm{HCO}_{3}{ }^{-}+\mathrm{OH}^{-} \rightarrow \mathrm{CO}_{3}{ }^{2-}+\mathrm{H}_{2} \mathrm{O}$ ). Reducing the concentration of $\mathrm{Ca}^{2+}$ and $\mathrm{Mg}^{2+}$ to $0.3 \mathrm{mM}$ and $0.5 \mathrm{mM}$, respectively, was proved to be an effective approach to avoid precipitation, and showed no significant reduction of biomass and $\beta$-carotene accumulation. In order to reduce production cost, seawater with $\mathrm{NaHCO}_{3}$ supply may be used for $D$. salina cultivation, in which $\mathrm{Ca}^{2+}$ and $\mathrm{Mg}^{2+}$ concentration is about 9-12.5 mM, and $80.5 \mathrm{mM}$, respectively [21,22]. These are much higher than $0.3 \mathrm{mM}$ and $0.5 \mathrm{mM}$, thus excessive $\mathrm{Ca}^{2+}$ and $\mathrm{Mg}^{2+}$ need to be removed via pretreatment. Precipitation with carbonate may be used as a simple method, and $\mathrm{CO}_{2}$ bubbling could regenerate bicarbonate afterwards, which may provide inorganic carbon as in this study [23].

This study first reported the effect of microelements on $\beta$-carotene accumulation in D. salina when $\mathrm{NaHCO}_{3}$ is used as carbon source. The result indicated $\mathrm{FeCl}_{3} \cdot 6 \mathrm{H}_{2} \mathrm{O}$ has a negative effect on cell biomass and $\beta$-carotene content with bicarbonate as carbon source. These findings were in accordance with previous research with $\mathrm{CO}_{2}$ as carbon source, and the amount of $\mathrm{FeCl}_{3} \cdot 6 \mathrm{H}_{2} \mathrm{O}$ supplied in this study may induce the generation of active oxygen molecules, and result in a negative effect on biomass and positive effect on $\beta$-carotene accumulation $[11,19]$. As shown in this study, $\mathrm{CoCl}_{2} \cdot 6 \mathrm{H}_{2} \mathrm{O}$ has negative effect on cell growth but positive effect on $\beta$-carotene accumulation. There was no report on this topic when D. salina is cultivated with $\mathrm{CO}_{2}$, but the study on Platymonas subcordiforus, Chaetoceros curvisetus and Skeletonema costatum did show that $\mathrm{Co}^{2+}$ inhibition to cell growth in that it affects the interactions among the thylakoid membrane protein-pigment complexes, and obstructs the reaction center of PSII [24]. Also, it was reported that $\mathrm{Co}^{2+}$ contributes to the accumulation of carotenoids in Pavlova viridis, since it is an oxidative stress-inducing factor to react with hydrogen peroxide through a Fenton-type reaction to generate hydroxyl radicals [25], and these findings are in accordance with this study. This study also indicated that $\mathrm{NaVO}_{3}$ concentration had positive effect on biomass but had no significant effect on $\beta$-carotene accumulation when cultured with $\mathrm{NaHCO}_{3}$, and there was no previous report on this in D. salina cultivated with $\mathrm{CO}_{2}$. It was reported that $2.5 \mathrm{mM} \mathrm{NaVO}_{3}$ promoted astaxanthin production in $\mathrm{H}$. pluvialis, and the possible mechanism is the inhibited expression of PTPases (Protein Tyrosine Phosphatases) by $\mathrm{NaVO}_{3}$ [26-28]. However, the $\mathrm{NaVO}_{3}$ concentration used in this study was only $2.62 \mu \mathrm{M}$, which may be too low to induce $\beta$-carotene accumulation.

The mechanism of improved $\beta$-carotene content under $\mathrm{NaHCO}_{3}$-based culture was unknown and there is little information available on the responses of photosynthetic electron flow, especially in photosystem II (PSII) to $\mathrm{NaHCO}_{3}$-based in D. salina. In the present study, the variation of $F_{v} / F_{m}$ exhibited similar patterns under two carbon supply conditions, but the $\mathrm{NaHCO}_{3}$-based culture resulted in lower $F_{v} / F_{m}$ values than that of $\mathrm{CO}_{2}$. Also, the $\mathrm{pH}$ value was higher at $\mathrm{NaHCO}_{3}$-based culture than that of $\mathrm{CO}_{2}$. Higher $\beta$-carotene accumulation may be attributed to both high concentration $\mathrm{NaHCO}_{3}$ and high $\mathrm{pH}$. It was reported that higher extracellular $\mathrm{NaHCO}_{3}$ concentration leads to a higher intracellular $\mathrm{pH}$, which may damage or inhibit the enzymes involved in

Table 7. $\beta$-carotene accumulation by strains of Dunaliella under varied cultivation conditions.

\begin{tabular}{|c|c|c|c|c|c|c|c|c|}
\hline Microalgae & $\begin{array}{l}\text { Initial } \\
\text { cell } \\
\text { density }\end{array}$ & $\begin{array}{l}\mathrm{L} / \mathrm{D} \\
\text { cycle }\end{array}$ & $\begin{array}{c}\text { Light } \\
\text { intensity } \\
\left(\mu \mathrm{mol} / \mathrm{m}^{-2} / \mathrm{s}^{-1}\right)\end{array}$ & $\begin{array}{l}\text { Culture } \\
\text { time } \\
\text { (d) }\end{array}$ & $\begin{array}{c}\beta \text {-carotene } \\
\text { content }\end{array}$ & $\begin{array}{c}\beta \text {-carotene } \\
\text { yield } \\
(\mathrm{mg} / \mathrm{l})\end{array}$ & $\begin{array}{l}\text { Carbon } \\
\text { source }\end{array}$ & Reference \\
\hline D. salina $\mathrm{V}-101$ & - & $16 / 8$ & 50 & 7 & $0.05 \%$ & $8.25 \pm 0.01$ & $\begin{array}{l}100 \mathrm{mM} \\
\mathrm{NaHCO}_{3}\end{array}$ & $\begin{array}{l}\text { Ramachandran } \\
\text { Svasanini et al., } \\
2018 \text { [12] }\end{array}$ \\
\hline D.salina CCAP 19/30 & - & $12 / 12$ & 200 & 7 & - & 1.2 & $\begin{array}{l}10 \mathrm{mM} \\
\mathrm{NaHCO}_{3}\end{array}$ & $\begin{array}{l}\text { Yanan Xu et al., } \\
2016\end{array}$ \\
\hline D. salina UTEX 2538 & - & $12 / 12$ & 1000 & 5 & - & 13.2 & $\begin{array}{l}10 \mathrm{mM} \\
\mathrm{NaHCO}_{3}\end{array}$ & $\begin{array}{l}\text { Yanan Xu et al., } \\
\text { 2018(Xu et al. } \\
\text { 2018) }\end{array}$ \\
\hline Dunaliella sp. & 0.1 & - & 340 & 17 & - & $20.43 \pm 2.84$ & $\begin{array}{l}60 \mathrm{mM} \\
\mathrm{NaHCO}_{3}\end{array}$ & $\begin{array}{l}\text { Ga-Yeong Kim } \\
\text { et al., } 2017 \text { [7] }\end{array}$ \\
\hline Dunaliella sp. & 0.1 & $16 / 8$ & 22 & 28 & $0.18 \%$ & $7.10 \pm 0.08$ & $\begin{array}{l}150 \mathrm{mM} \\
\mathrm{NaHCO}_{3}\end{array}$ & $\begin{array}{l}\text { Srinivasan et } \\
\text { al., 2015 [9] }\end{array}$ \\
\hline D. salina CCAP 19/18 & $0.2 \times 10^{6}$ & $12 / 12$ & 200 & 7 & $4.50 \%$ & 32.0 & $\begin{array}{l}200 \mathrm{mM}^{2} \\
\mathrm{NaHCO}_{3}\end{array}$ & This study \\
\hline
\end{tabular}


photosynthesis and reduce the efficiency of PSII photosystem $\left(F_{v} / F_{m}\right)$ [29]. Also, it was reported that higher $\mathrm{NaHCO}_{3}$ concentration (above $0.6 \mathrm{mM}$ ) in the culture could inhibit the extracellular carbonic anhydrase (CA) activity, which is an important enzyme catalyzing the reversible dehydration of $\mathrm{HCO}_{3}{ }^{-}$to $\mathrm{CO}_{2}$, and decline of CA activities has significant inhibition of effective quantum efficiency of PSII, and thus reduce the value of $F_{v} / F_{m}[30]$. It was reported that decreased PSII activity results in the increase of ROS concentration, and $\beta$-carotene is synthesized to scavenge the ROS [31]. This may be the reason why increased $\beta$-carotene content was observed in culture with high concentration of $\mathrm{NaHCO}_{3}$. However, the connection between ROS and $F_{v} / F_{m}$ under $\mathrm{NaHCO}_{3}$ stress in microalgae is still unknown and further in-depth research is needed to disclose the mechanism.

From the above results, $\mathrm{FeCl}_{3} \cdot 6 \mathrm{H}_{2} \mathrm{O}, \mathrm{NaVO}_{3}$ and $\mathrm{CoCl}_{2} \cdot 6 \mathrm{H}_{2} \mathrm{O}$ concentrations significantly influenced $D$. salina biomass production with $\mathrm{NaHCO}_{3}$ as carbon source, which was not reported in cultivation with $\mathrm{CO}_{2}$. The notable difference in $F_{v} / F_{m}$ value between cultivations with bicarbonate and $\mathrm{CO}_{2}$ indicates that $\mathrm{NaHCO}_{3}$ acts as a stress factor for $\beta$-carotene production more so than $\mathrm{CO}_{2}$, and may make it useful in an easy and effective $\beta$-carotene induction method.

\section{Acknowledgments}

This research was supported by the Fundamental Research Funds for the Central Universities (No. DUT17RC (3)090).

\section{Conflict of Interest}

The authors have no financial conflicts of interest to declare.

\section{References}

1. Bonnefond H, Moelants N, Talec A, Bernard O, Sciandra A. 2016. Concomitant effects of light and temperature diel variations on the growth rate and lipid production of Dunaliella salina. Alga. Res. 14: 72-78.

2. Bonnefond H, Moelants N, Talec A, Mayzaud P, Bernard O, Sciandra A. 2017. Coupling and uncoupling of triglyceride and betacarotene production by Dunaliella salina under nitrogen limitation and starvation. Biotechnol. Biofuels. 10: 25.

3. Gong M, Bassi A. 2016. Carotenoids from microalgae: a review of recent developments. Biotechnol. Adv. 34: 1396-1412.

4. Chekanov K, Schastnaya E, Solovchenko A, Lobakova E. 2017. Effects of $\mathrm{CO}_{2}$ enrichment on primary photochemistry, growth and astaxanthin accumulation in the chlorophyte Haematococcus pluvialis. J. Photochem. Photobiol. B. 171: 58-66.

5. Doucha J, Straka F, Livansky K. 2005. Utilization of flue gas for cultivation of microalgae (Chlorella sp.) in an outdoor open thin-layer photobioreactor. J. Appl. Phycol. 17: 403-412.

6. Posten C. 2009. Design principles of photo-bioreactors for cultivation of microalgae. Eng. Life Sci. 9: 165-177.

7. Kim GY, Heo J, Kim HS, Han JI. 2017. Bicarbonate-based cultivation of Dunaliella salina for enhancing carbon utilization efficiency. Bioresour Technol. 237: 72-77.

8. Kim J, Lee JY, Lu T. 2014. Effects of dissolved inorganic carbon and mixing on autotrophic growth of Chlorella vulgaris. Biochem. Eng. J. 82: $34-40$

9. Srinivasan R, Kumar VA, Kumar D, Ramesh N, Babu S. 2015. Gothandam KM, Effect of Dissolved Inorganic Carbon on betaCarotene and Fatty Acid Production in Dunaliella sp. Appl. Biochem. Biotechnol. 175: 2895-2906.

10. Zhu C, Zhu H, Cheng L, Chi Z. 2017. Bicarbonate-based carbon capture and algal production system on ocean with floating inflatable-membrane photobioreactor. J. Appl. Phycol. 30: 875-885.

11. Saha SK, Moane S, Murray P. 2013. Effect of macro- and micro-nutrient limitation on superoxide dismutase activities and carotenoid levels in microalga Dunaliella salina CCAP 19/18. Bioresour. Technol. 147: 23-28.

12. Srinivasan R, Mageswari A, Subramanian P, Suganthi C, Chaitanyakumar A, Aswini V, et al. 2018. Bicarbonate supplementation enhances growth and biochemical composition of Dunaliella salina V-101 by reducing oxidative stress induced during macronutrient deficit conditions. Sci. Rep. 8: 6972.

13. Fachet M, Hermsdorf D, Rihko-Struckmann L, Sundmacher K. 2016. Flow cytometry enables dynamic tracking of algal stress response: a case study using carotenogenesis in Dunaliella salina. Algal. Res. 13: 227-234.

14. Lamers PP, Janssen M, De Vos RCH, Bino RJ, Wijffels RH. 2012. Carotenoid and fatty acid metabolism in nitrogen-starved Dunaliella salina, a unicellular green microalga. J. Biotechnol. 162: 21-27.

15. Xupeng Cao, Yimei Xi, Jiao Liu, Yadong Chu, Peichun Wu, Miao Yang, et al. 2019. New insights into the $\mathrm{CO}_{2}$-steady and pH-steady cultivations of two microalgae based on continuous online parameter monitoring. Algal Res. 38: 101370.

16. Fazeli MR, Tofighi H, Madadkar-Sobhani A, Shahverdi AR, Nejad-Sattari T, Mirzaie S, et al. 2009. Nicotine inhibition of lycopene cyclase enhances accumulation of carotenoid intermediates by Dunaliella salina CCAP 19/18. Eur. J. Phycol. 44: 215-220.

17. Chi L, Yao C, Cao X, Xue S. 2016. Coordinated regulation of nitrogen supply mode and initial cell density for energy storage compounds production with economized nitrogen utilization in a marine microalga Isochrysis zhangjiangensis. Bioresour. Technol. 200: 598-605.

18. Meng Y, Jiang J, Wang H, Cao X, Xue S, Yang Q, et al. 2015. The characteristics of TAG and EPA accumulation in Nannochloropsis oceanica IMET1 under different nitrogen supply regimes. Bioresour. Technol. 179: 483-489.

19. Mojaat M, Pruvost J, Foucault A, Legrand J. Effect of organic carbon sources and $\mathrm{Fe}^{2+}$ ions on growth and beta-carotene accumulation by Dunaliella salina. Biochem. Eng. J. 39: 177-184.

20. Lamers PP et al. 2010. Carotenoid and fatty acid metabolism in light-stressed Dunaliella salina. Biotechnol. Bioeng. 106: 638-648.

21. Md. Abu Affan, Lee DW, Jeon SM, Noh JH, Heo SJ, Oh CH, et al. 2015. Bituminous coal and soium hydroxide-pretreated seawater stimulates Spirulina (Arthrospira) maxima growth with decreased production costs. Aquaculture 436: 121-126.

22. Besson A, Guiraud P. 2013. High-pH-induced flocculation-flotation of the hypersaline microalga Dunaliella salina. Bioresour. Technol. 147: 464-470

23. Zhu C, Zhai X, Chi Z. 2018. Seawater desalination concentrate for cultivation of Dunaliella salina with floating photobioreactor to produce beta-carotene. Algal Res. 35: 319-324.

24. Chen XH, Zhang C, Tan LJ, Wang JT. 2018. Toxicity of Co nanoparticles on three species of marine microalgae. Environ. Sci.Pollut. R. 236: 454-461

25. Mei L, Qin Z, Hu C-W, Li C, Liu Z-L, Kong Z-M. 2007. Cobalt and manganese stress in the microalga Pavlova viridis (Prymnesiophyceae): effects on lipid peroxidation and antioxidant enzymes. J. Environ. Sci. 19: 1330-1335.

26. Chen WL, Harris DL, Joyce NC. 2005. Effects of SOV-induced phosphatase inhibition and expression of protein tyrosine phosphatases in rat corneal endothelial cells. Exp.Eye Res. 81: 570-580. 
27. Du Z-D, Hu L-T, Hu Y-T, Ma Z-Z. 2010. The effects of sodium orthovanadate-induced phosphatase inhibition on rat retinal pigment epithelium cell activity. Cutan. Ocul. Toxicol. 29: 261-268.

28. Tran NP, Park JK, Kim ZH, Lee CG. 2009. Influence of sodium orthovanadate on the production of nastaxathin from green algae Haematococcus lacustris. Biotechnol. Bioproc. E. 14: 322-329.

29. Ying K, James Gilmour D, Zimmerman WB. 2014. Effects of $\mathrm{CO}_{2}$ and $\mathrm{pH}$ on Growth of the Microalga Dunaliella salina. J. Microb. Biochem. Technol. 6: 167-173.

30. Liu W, Ming Y, Li P, Huang Z. 2012. Inhibitory effects of hypo-osmotic stress on extracellular carbonic anhydrase and photosynthetic efficiency of green alga Dunaliella salina possibly through reactive oxygen species formation. Plant Physiol. Biochem. 54: 43-48.

31. Zheng Z, Gao S, Hee Y, Li Z, Li Y, Cai X, et al. 2017. The enhancement of the oxidative pentose phosphate pathway maybe involved in resolving imbalance between photosystem I and II in Dunaliella salina. Algal Res. 26: 402-408. 